FORESTRY - FARMING LINKAGES IN THE MOUNTAINS

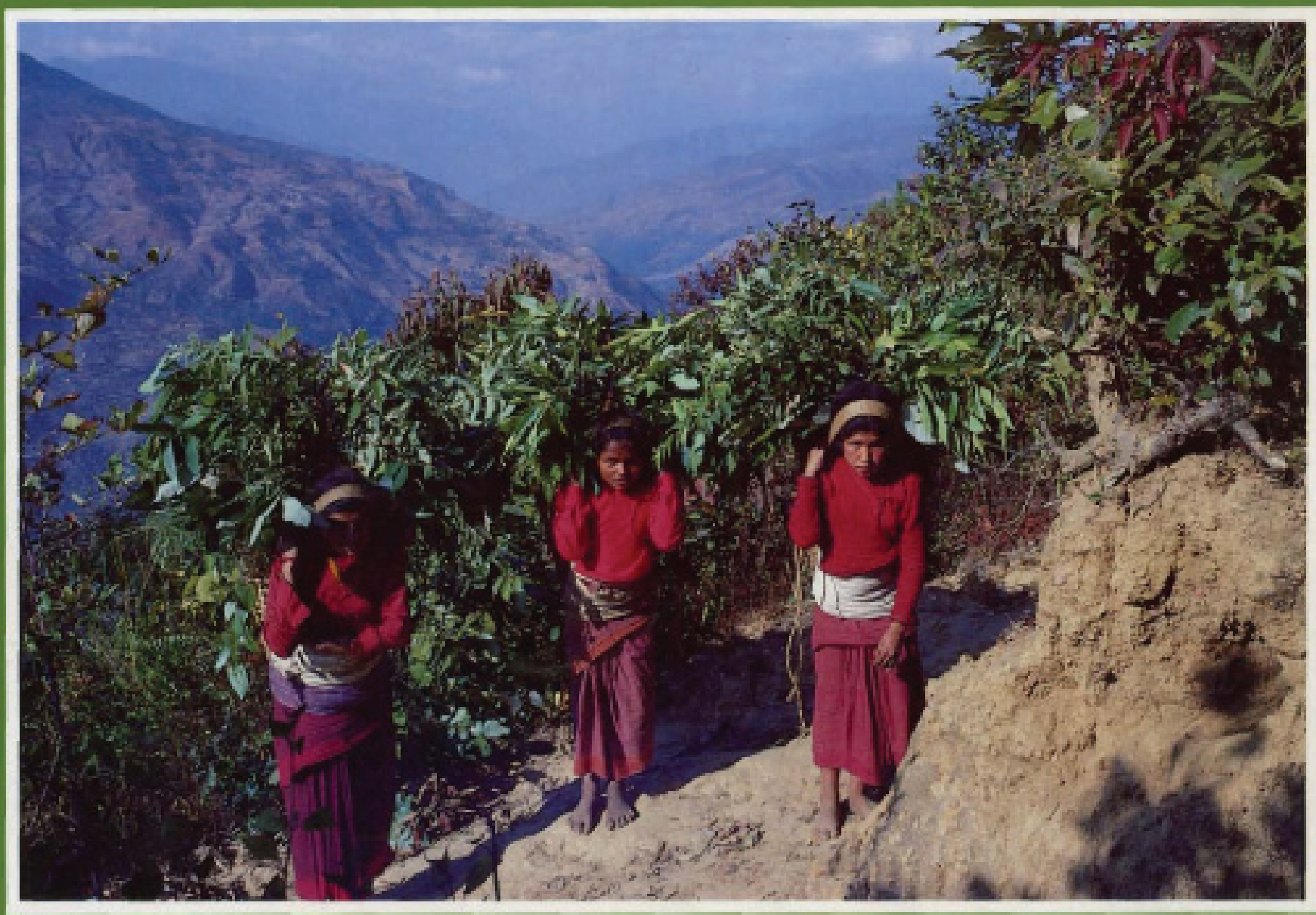

T.B.S. Mahat

ICIMOD OCCASIONAL PAPER NO. 7

Kathmandu, Nepal

March, 1987 
ICIMOD Occasional Papers

No. 1

EROSION AND SEDIMENTATION PROCESSES IN THE NEPALESE HIMALAYA Brian Carson

August 1985.

\section{No. 2}

INTEGRATED RURAL DEVELOPMENT PROJECTS IN NEPAL: A REVIEW

Bharat B. Pradhan

December 1985.

\section{No. 3}

SUSTAINING UPLAND RESOURCES: PEOPLE'S PARTICIPATION IN WATERSHED MANAGEMENT

Anis Ahmad Dani and J. G. Campbell

July 1986.

No. 4

DECENTRALISED ENERGY PLANNING AND MANAGEMENT FOR THE HINDU KUSHHIMALAYA

Deepak Bajracharya

September 1986.

No. 5

GLACIAL LAKE OUTBURST FLOODS AND RISK ENGINEERING IN THE HIMALAYA Jack D. Ives

November 1986.

No. 6

OPERATIONAL EXPERIENCES IN FOREST MANAGEMENT DEVELOPMENT IN THE HILLS OF NEPAL

G. B. Applegate and D. A. Gilmour

January 1987.

No. 7

FORESTRY - FARMING LINKAGES IN THE MOUNTAINS

T. B. S. Mahat

March 1987.

No. 8

ROAD CONSTRUCTION IN THE NEPAL HIMALAYA: THE EXPERIENCE FROM THE LAMOSANGU - JIRI ROAD PROJECT

Urs Schaffner

March 1987. 


\section{FORESTRY - FARMING LINKAGES}

IN THE MOUNTAINS

T. B. S. Mahat

ICIMOD OCCASIONAL PAPER NO. 7

Interuational Centre for Integrated Mountain Development

Kathmandu, Nepal 


\section{Copyright@ 1987}

International Centre for Integrated Mountain Development

All rights reserved

Cover photograph: Fuel and Fodder collection in Sindhu Palchok District

\section{Published by}

International Centre for Integrated Mountain Development,

G. P. O. Box 3226, Kathmandu, Nepal

in association with Kefford Press, Singapore

ISBN 9971-84-832-5

The views and interpretation in this paper are the author's and are not attributable to the International Centre for Integrated Mountain Development (ICIMOD), and do not imply the expression of ary opinion concerning the legal status of any country, territory, city or area of its authorities, or concerning the delimitation of its frontiers or boundaries. 
The consideration of forests as a free and abundant resource, in some cases waiting to be cleared in order to make the land "productive", is slowly changing into deeper understanding, not only of the intimate relationship between forests, livestock and agricultural productivity, but also of the many ways in which forest and tree products contribute directly to the food and income requirements of the mountain people.

The present joint study by the Food and Agriculture Organization of the United Nations (FAO) and the International Centre for Integrated Mountain Development (ICIMOD) documents and provides examples of these relationships. It also shows the high degree of flexibility and adaptation to new levels of resource scarcity shown by the mountain communities themselves. However, it points to the urgency of external support and new investments if widespread human suffering and ecological damage is to be avoided.

We wish to express our recognition of the value of this study by Dr. T.B.S. Mahat with the professional participation of Mr. J-P. Jeanrenaud and Mrs. R. L. J. Shrestha, and our gratitude to the many people who gave their time and contribution to the document.

It is hoped that the study will stimulate interest in the rehabilitation of upland areas through investment in forestry activities as an integral part of a diversified mountain economy.

\author{
J. P. Lanly \\ Director \\ Forest Resources Division \\ Forestry Department \\ F.A.O
}

Colin Rosser

Director

ICIMOD 
The author thanks the Food and Agriculture Organisation of the United Nations, Forestry Department and the International Centre for Integrated Mountain Development for co-sponsoring this study.

This paper has evolved out of the earlier ICIMOD working papers on the subject which, because of the unconventional nature of the subject matter chosen, has been a rather complex and difficult task. The author is indebted to Mr. J-P. Jeanrenaud and Mrs. R.L.J. Shrestha, his colleagues in this study, who provided valuable assistance through research and contribution on the earlier working papers. Mr. J-P. Jeanrenaud has not only provided material for this paper, particularly to the sections on Daphne Paper, Bamboo and Allo Cloth, but has also made a valuable contribution to the better understanding of Nepal's lesser known forest resources for rural income generation by way of his already published work on Daphne (Lokta) paper making in Nepal. Mrs. R.L.J. Shrestha provided the economic analysis and other material, in particular the case studies of the Nepal-Australia Forestry Project, Medicinal Plants Development and Mushroom Farming.

The author is grateful to Dr. Colin Rosser, Director, ICIMOD for his valuable advice and keen interest throughout the course of the study. Sincere thanks are due to Mr. T. Michaelsen, Mr. L. S. Botero and Dr. K. D. Singh of the FAO, Forestry Department (Rome); Dr. R. V. Singh and Mr. P. Keshwani of the Forest Research Institute \& College (Dehra Dun); Dr. K. R. Shepherd of the Australian National University, Forestry Department (Canberra); and Dr. Kk. Panday and Dr. R. P. Yadav of ICIMOD for their intellectual contribution.

The author acknowledges the support of Ms. S. Kasa ju, Ms. R. Shreshtha, Ms. S. Gurung and ICIMOD's Editorial and Publication Unit.

The views expressed in this paper are those of the author and do not necessarily represent the views of ICIMOD or FAO. 


\begin{tabular}{|c|c|}
\hline ADAB & Australian Development Assistance Bureau \\
\hline $\mathrm{ADB} / \mathrm{HMG}-\mathrm{N}$ & $\begin{array}{l}\text { Asian Development Bank/ } \\
\text { His Majesty's Government of Nepal }\end{array}$ \\
\hline APROSC & Agricultural Projects Services Centre \\
\hline BLU & Big Livestock Unit \\
\hline c. & ca., circa, about \\
\hline CBS & Central Bureau of Statistics \\
\hline $\mathrm{FAO} / \mathrm{UN}$ & Food and Agriculture Organization of the United Nations \\
\hline HK-H Region & Hindu Kush-Himalaya (Mountain) Region \\
\hline HMG-N & His Majesty's Government of Nepal \\
\hline ICIMOD & International Centre for Integrated Mountain Development \\
\hline Kabhre & Kabhre Palanchok \\
\hline KHARDEP & Koshi Hill Area Rural Development Project \\
\hline NAFP-2 & Nepal-Australia Forestry Project. Stage-2 \\
\hline PF & 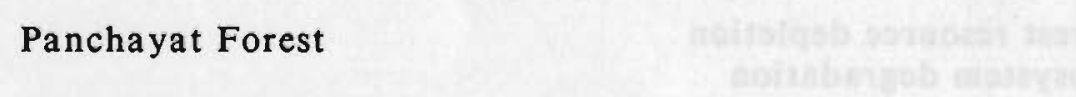 \\
\hline PPF & Panchayat Protected Forest \\
\hline SFDP & Small Farmers' Development Programme \\
\hline TDN & Total Digestible Nutrient \\
\hline TSU & Tree Seed Unit \\
\hline UNDP & United Nations Development Programme \\
\hline USAID & United States Agency for International Development \\
\hline $\mathrm{mt}$ & Metric Tonne \\
\hline
\end{tabular}


TABLE OF CONTENTS

Page

FOREWORD

ACKNOWLEDGEMENTS

ABBREVIATIONS

iii

INTRODUCTION

FORESTRY - HILL FARMING RELATIONSHIPS

Fuelwood

Fodder

Leaf-litter - Organic compost manure

Poles and timber for rural construction and implements

Forest products for direct domestic consumption

Forest products for supplementary income generation

Summary

THE HILL FARMER'S PROBLEM

Enhancing the hill farmer's income

Problem of forest resource depletion

Problem of ecosystem degradation

The hill farmer's response

Agricultural land extension

Agriculture intensification

Off-farm employment opportunity

Out-migration

Summary

ADDITIONAL INCOME GENERATION THROUGH

FORESTRY ACTIVITIES AND INVESTMENTS

CASE STUDIES

Reforestation and management of existing forests and trees

The Nepal-Australia Forestry Project, Stage-2 (NAFP-2) 
The development of small scale industries

Bast paper making industry in Nepal

Bamboo and allied industries

Cloth production from the fibres of the Himalayan Nettle: Allo

Fruits and other cash crops production

Fruit growing

Medicinal plant development in Nepal

35

Mushroom farming 


\section{LIST OF ILLUSTRATIONS}

\section{TABLES}

1. Investment related to forest products development

2. Investment related to forestry institutional and inf rastructural development

3. Area of plantation established by NAFP

4. Internal rate of return of various planting strategies

5. Lokta Collection: Employment and Income

6. Paper Production: Employment and Income

7. Allo Cloth Production: Cost Breakdown

8. Orchards and apple trees in Thak Khola

\section{FIGURES}

1. Biomass fuel sources

\section{PLATES}

1. Farmer managed forest and terraced cropland in Banskharka

Sindhu Palchok district.

2. Trees on hill farmland maintained for livestock fodder and fuelwood

3. Fuelwood collection

4. Tree leaves and branches for fodder and fulewood

5. Organic manure from forest biomass mixed with animal excreta, the principal source of soil nutrient for hill agricultural land

6. Farm implements made from wood

7. Disabled hill farmer earns a living by bamboo goods manufacturing 